\title{
The Shift of the Valuation and Management Model in Japanese Protected Townscapes from a Tourism Point of View to a Local Community and Environment Point of View: Case Studies of Uchiko (1978-82), Kurayoshi (1998) and Ine (2004-05)
}

\author{
By Jon Alvarez*
}

The Japanese government's efforts to value and preserve traditional townscapes, which commenced in 1975, gave birth to the denken chiku (Japanese abbreviation for 'Important Districts of Traditional Built Structures') programme, whereby the Agency for Cultural Affairs established the valuation criteria for townscapes alongside a system of grants to ensure their survival. Before 1990, economic expansion had led to widespread economic changes that transformed both Japan's space and its population. Rural areas were depopulated and their economies ruined. Tourism, which was a potential new source of income, especially in rural areas, was thus prioritised in townscape protection system criteria. Most of the urban and rural designated townscapes were viable for tourism (i.e., appealing to tourists) and easily accessible (e.g., by express train). However, by 1990, when the Japanese economic bubble burst, the tourism-centred model declined along with the economy. This triggered a shift in townscape valuation: local needs and growth were prioritised over tourism appeal, the local community came to be viewed as the main agent of conservation, and the preservation of the landscape was recast as an opportunity for territorial development. As local communities are easier to recognise in small, rural locales, most of the townscapes designated since 1990 have been rural and difficult to access. Management has also changed from a public worker-centred model to a local association-centred one. The three case studies examined in this paper describe the realities of three different historical stages of Japanese architectural preservation. Stage 1 (1976-1989), which developed along with the Japanese asset price bubble, saw the development of protection plans oriented to the tourism industry as a solution to the problem of rural decline. The elements considered valuable and in need of protection were those that made the protected town understandable and attractive to tourists: the external elements of buildings were prioritized over other spatial relations, such as that between the interior and exterior living spaces of the local population. Stage 2 (1990-2003) saw the failure of the tourism model, since even a massive tourism boom could never compensate for the decline of rural heritage sites. This was an opportunity for other towns, with little touristic interest but significant historic value, to enter the denken chiku system. The socio-spatial structures that ensured the survival of towns, such as old trade routes and infrastructure, were now considered valuable, as were the needs of the community. The beginning of stage 3 (2004- ) was marked by the 2004 Landscape Law. Each of these three stages has brought about different results that help us picture the current state of Japanese townscape heritage.

${ }^{*}$ Doctor of Architecture, Waseda University, Japan. 


\section{Introduction}

In 1975, an amendment to the Japanese law governing the protection of cultural assets introduced cultural townscapes as a new protected category. The starting point for the protection of cultural townscapes had been two lines of research and two legal corpora: the protection of the landscape and the protection of traditional Japanese dwellings. The Japanese government employed the term kenzōbutsugun (literally 'groups of traditional built structures') to define the cultural townscapes to protect. Groups of houses were valuable in themselves, regardless of whether any monument in particular existed within the group. However, many traditional building groups were disappearing because of the tendency towards a scrap-and-build approach arising out of the 1960s, which was made possible by the strong landowner rights. ${ }^{1}$ These landowner rights would also be a major differentiator factor in Japanese townscape protection. Since landowner rights could not be regulated by any urban plan or ordinance, the possible actions had to be concentrated in works on the structures, instead of urban planning and management instruments. Scrap-and-build, being impossible to restrict through urban planning, became the principal threat to cultural townscapes. Consequently, the avoidance of scrap-and-build activity would become the initial goal of townscape preservation. To that end, the Japanese approach of 'preservation through use' was considered the most viable. Thus, local community groups necessarily played a leading role in the definition of the values to protect, as well as in conservation efforts. Starting in the 1960s, these local communities, especially in rural areas, had seen protection not only as a means to avoid scrapand-build, but also as an opportunity to revitalise their decaying towns through tourism. Thus, instead of focusing on historic and aesthetic value alone, Japanese townscape preservation also included a strong functional and economic valuation.

The implementation of the protection of cultural townscapes was conducted through a new category, named jüyō dentōteki kenzōbutsugun hozon chiku (literally 'protected districts of important groups of traditional buildings', hereafter denken chiku), which defined a protected area inside a defined perimeter, with no buffer zones between protected and unprotected urban zones. By early 2015, the Japanese government had designated 109 districts throughout Japan as denken

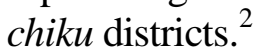

Nevertheless, the evolution of designations was neither uniform nor based on the same criteria from 1975 until the present day. Between 1972 and the publication of the law amendment, the Japanese Agency for Cultural Affairs created a research group to register those towns and districts eligible to enter the denken chiku category; thus, the vast majority of the currently designated towns were known before 1975. Yet, while some of the districts were designated as early as 1976, others that were initially included in the study were discarded at the early stages of the implementation before later being recovered. In previous studies, we

1. M. Yamasaki, "Control tools for conservation of historic townscape with citizens' strong property right: Experience of Kyoto," in ICOMOS 15th General Assembly and Scientific Symposium, 2005.

2. ACA-Agency for Cultural Affairs, Rekishi wo ikashita machizukuri, Tokyo, 2015. 
examined the criteria used to value and prioritize the designation of some districts over others. We concluded that the valuation undertaken by the Agency for Cultural Affairs had evolved through three distinct temporal stages: ${ }^{3}$

- Stage 1 (1975-1990). In this stage, Japan experienced an economic bubble, characterised by the rapid development of the urban landscape and the simultaneous decay of rural areas. In this stage, the goals of townscape protection were those mentioned above: protection against scrap-and-build in urban areas, ${ }^{4}$ and local development through tourism in rural areas. In these rural areas, the population was rapidly declining and ageing, and tourism was to be the key to the reversal of this trend. This is also the period in which the workflow of the denken chiku system was defined: the Agency for Cultural Affairs extended a series of grants every year to finance interventions - performed locally in each district - aimed at preserving the external aspect of traditional buildings, while adapting nontraditional structures to the same aesthetics. As a result of this workflow, the designated districts in this stage were formally easy to recognize, in addition to being accessible to tourists via new express trains.

- Stage 2 (1990-2003). After the bubble burst, both scrap-and-build activity and tourism declined. At the same time, local groups against kankō kōgai (literally 'tourism pollution') made an appearance in several towns that had suffered transformations due to touristic activity. At this stage, the policies focused on improving the living environment of local communities, while making them compatible with a modern lifestyle. The importance of tourism in decision-making declined. Many of the districts designated at this stage had been researched during the previous one, ${ }^{5}$ but their designation took longer because they did not fit the tourism-oriented model.

- Stage 3 (2004-). In 2004, the Landscape Law was passed, and the landscape was for the first time included among the protected elements. Consequently, the number of inaccessible rural areas included under the law's protection increased significantly.

In summary, the values considered in the designation of new protected districts underwent an evolution throughout these three stages. In this context, this paper aims at explaining how these criteria for valuation, decided by the national government, influenced subsequent town planning and management by local governments. Since the focal point of the designation evolved by moving away

3. J. Alvarez, "Significance of tourism and local communities. A study of the shift in valuation criteria of Japanese protected townscapes," in Journal of Architecture and Planning 82, no. 736 (2017), 1619-1629.

4. U. Nishiyama, Rekishiteki keikan to machizukuri (Tokyo: Toshi Bunkasha, 1990); U. Hohn, "Townscape Preservation in Japanese Urban Planning," in The Town Planning Review 68, no. 2 (April 1997).

5. F. Kobayashi and M. Kawakami, "Policies implemented in the application process of preservation districts for groups of historic buildings," in Journal of Architecture and Planning 68, no. 567 (May 2003), 87-94. 
from a tourism-centred approach, the question is how local governments and communities managed to protect and guarantee the future of townscapes in areas unsuitable for intensive tourism. For that purpose, this paper examines three casestudies, one for each stage defined above. All three are located in rural areas, away from large urban centres and major infrastructure such as bullet trains or international airports. The research methodology included thorough archival research, including a review of every survey and plan related to each of the protected districts, as well as field research to study the current state of built structures and urban systems as a consequence of the implementation of the protection plans.

\section{Case Study 1, Uchiko (1978-82)}

\section{Starting Point and Motivation for Preservation Efforts}

The first case study is Yōkaichi Gokoku district, which forms part of the old town in Uchiko. Uchiko is located on the island of Shikoku, which at the time of the designation was the only island not connected to the others by railway or any land transportation means. Uchiko had access to the railway network only through a small local line (the Uchiko Line), which had its last stop near the old town. This changed in 1986, when the new Yosan express line was opened through Uchiko. Nevertheless, Uchiko remained one of the least accessible protected districts between 1975 and 1990.

Uchiko is the perfect example of a rural town in decline after the 1960s and continuing to stagnate even during the asset price bubble. Located at a strategic crossing of roads and riverways, Uchiko had flourished as a hub for regional economic activity. It also served as a post town for the Ohenro pilgrimage route, as well as for regional trade routes towards Matsuyama and Osaka. During the $18^{\text {th }}$ and $19^{\text {th }}$ centuries, Uchiko had developed a wax production industry. Thus, in the old town, shop-dwelling building types are mixed with old wax factories and storehouses. Uchiko's economy began to decline after the opening of a new bypass road in 1968, an atrophy worsened by the subsequent changes in lifestyle caused by the use of private cars (Figure 1). As local trade waned, the local government explored alternative economic activities to preserve the town. Starting in the late 1970s, public workers at Uchiko's municipal office travelled to the first designated denken chiku to study their tourism models. ${ }^{6}$ Even if they realised that Uchiko was neither as easily accessible as most of the visited towns, nor boasted any famous cultural assets at the time, they decided to focus on tourism as a crucial component of future economic development and the valuation of the townscape by its inhabitants. Thus, in 1983, Uchiko launched its own plan to encourage tourism. ${ }^{7}$

6. Y. Nishimura, Shōgen. Machinami hozon (Kyoto: Gakugei shuppansha, 2007).

7. Uchiko Town, Uchiko no 'hikari' wo 'mi' naosō. Uchiko chō kankō shinkō keikakusho (Uchiko, 1983). 
The preliminary survey to obtain the designation as denken chiku was completed in 1978, and the designation by the Japanese Agency for Cultural Affairs came in 1982. However, Uchiko had already intervened in the external aspect of 29 buildings $^{8}$ in order to improve the town's touristic appeal and obtain the designation.

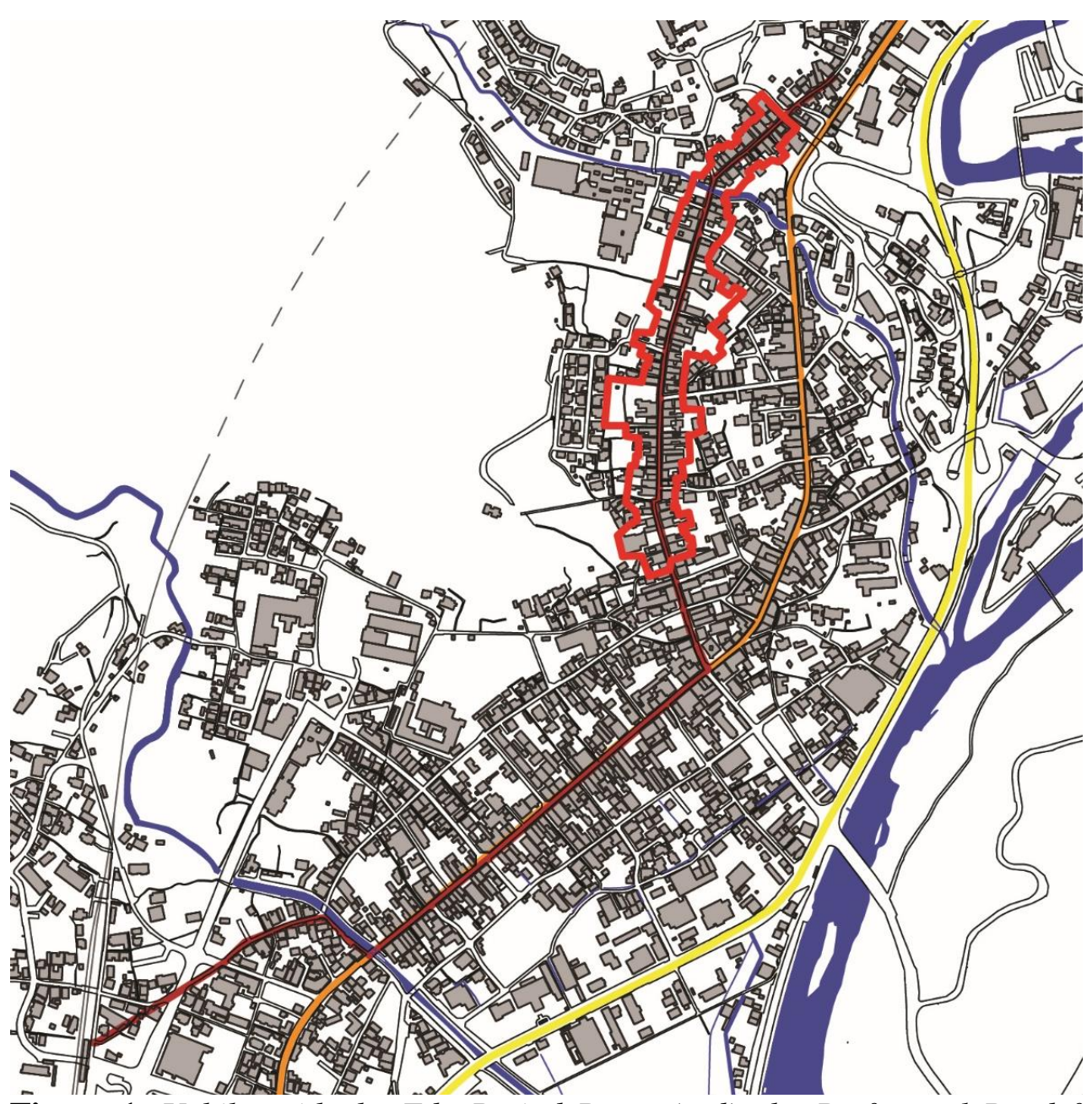

Figure 1. Uchiko with the Edo Period Route (red), the Prefectural Road from 1907 (orange), and the Prefectural 56 Route from 1968 (yellow)

Source: Drawn on map by Geospatial Information Authority of Japan, 2016.

8. Uchiko Town. Shūri shūkei kiroku. Uchiko chō Yōkaichi Gokoku dentōteki kenzōbutsugun hozon chiku (Uchiko, 2013). 


\section{Contents of the Plan}

The plan pivoted on the Uchikorashii ('typical Uchiko-ish') concept as the key point for the definition of the protected elements and policies. In the absence of famous temples or castles, Uchiko aimed at creating a new type of tourism asset out of its everyday living environment. This would include the shop-houses, as well as the factories still remaining. For that purpose, the plan defined the prime of Uchiko's history, between the late $18^{\text {th }}$ century and the $1920 \mathrm{~s}$, and then defined 'typical Uchiko-ish' building types for each historical period within this timeframe (Figure 2). In order to make these building types easier to identify, the floor plans of the district included in the plan reflected the 'typical' floorplans of each house at its prime, instead of their current condition. ${ }^{9}$ Thus, the buildings constructed in types defined prior to the 1860 s were drawn with storage spaces on their second floors, as they used to be at that time, while the building types common after the 1860s included zashiki-type parlours, intended for receiving guests and customers, as they had in the past. Moreover, this 'typical' approach included only those elements defining the 'typical' streetscape: the floor plans included only the main houses at the front of each plot of land and adjoining the street, while auxiliary buildings in the rear, such as storehouses, outbuildings or expansions of the old houses were excluded. The definition of the elements in these floorplans would remain when the plan defined those elements to preserve and the financial grants available for their preservation. ${ }^{10}$


Figure 2. Typical Shapes for a Dwelling from $18^{\text {th }}$ Century and $19^{\text {th }}$ Century, according to the Definitions in the Protection Plan

Source: Author, 2015.

Continuing with the definition of typical elements, the plan included a catalogue of typical built elements for façades, roofs and decorations. The catalogue also included finishing materials for plastered walls, elements for protection against fire, roofing tiles, rafters, decorative brackets and corbels, and

9. These floorplans were used in both the survey published in 1978 and a revision published in 1987, as in Uchiko Town, Uchiko chō dentōteki kenzōbutsugun chōsa hōkokusho (Uchiko, 1978) and Uchiko Town, Uchiko Muikaichi-Yōkaichi Gokoku chiku. Dentōteki kenzōbutsugun hozon chiku hozon taisaku chōsa hōkokusho (Uchiko, 1987).

10. Uchiko Town, Uchiko chō Yōkaichi Gokoku dentōteki kenzōbutsugun hozon chiku hozon taisakuhi hojokin kōfuyōmō (Uchiko, 1982). 
fixtures for doors and windows such as wooden lattices and sash windows. However, the plan did not include the way in which all these elements would be combined in the buildings.

Finally, the plan included a list of any emerging building that could itself potentially be used as a tourism asset. Inside the protected district, the main elements were the old factories, which were intended for use as public facilities such as information points and local museums. On the other hand, some other elements, such as the Uchikoza kabuki theatre, were placed outside the district, and were meant to be preserved for their original use while being connected to the old district through walking routes for tourists (Figure 3).

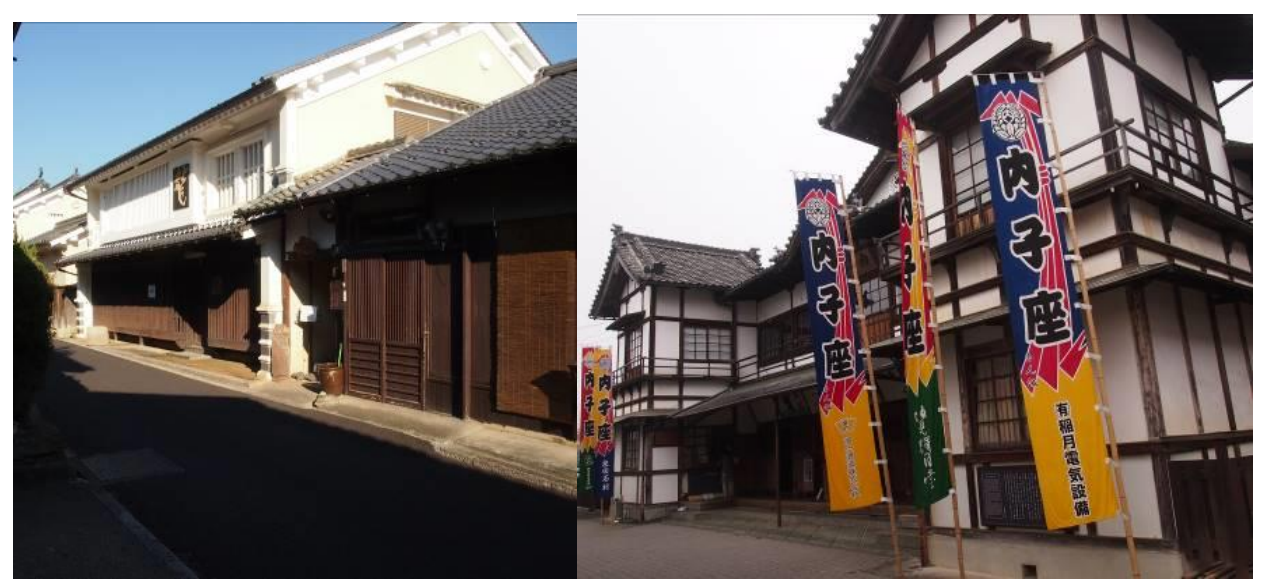

Figure 3. Emerging Buildings in Uchiko: Kamihaga house-Wax Museum and Uchikoza Kabuki Theatre

Source: Author, 2015.

\section{Management Model}

The management model in Uchiko is government-centred. In the 1970s, the sense of local community was not strong enough to confer the leading role to the inhabitants of Uchiko. ${ }^{11}$ Thus, it was the local government that contacted the previously designated districts and attempted to implement their model in Uchiko. The main goal of management is to create assets for tourism out of everyday life in Uchiko. For that purpose, the local government defined a network of museums inside and around the protected district to display the local lifestyle to visitors. In addition, to improve contact with local inhabitants, the Townscape Protection Centre was opened in a traditional house inside the district. This was intended to facilitate direct relations with individuals in the absence of local leadership through a community group. The model of tourism at which they aimed from the beginning had to be locally managed, while it had to enforce the recovery of local crafts as tourism assets. In consideration of the fact that Uchiko's local life was its principal tourism asset, one priority was avoiding the establishment of businesses

11. F. Okada, "Jūmin to rekishi isan mamori katsuseika. Machinami hozon de 'kaku' takameru," in Shōgai fōramu, no. 1163 (October 1996), 19-23; Okada, "Jūmin sanka ni yoru muranami hozon," in Gekkan jichi fōramu, no.483 (December 1999), 34-39. 
in the district run by outsiders to sell cheap, widely available souvenirs, and prioritising products linked to local life.

Public participation is implemented through the creation of ad hoc groups. These groups are not permanent, but rather created for the accomplishment of specific purposes and dissolved once their goals are attained. Currently, there are two main types of groups: sectorial groups, such as the farmers group, and territorial groups, such as each one of the agricultural communities from districts around central Uchiko. These groups are meant to act so as to create their own tourism assets. Thus, the farmers group established a local market (the Karari Fresh Market) near central Uchiko, where they sell their products and organize events to impart information about their activities and traditional techniques. Similarly, in rural districts, locals have refurbished traditional structures such as farms for the purpose of lodging tourists.

The local government is in permanent contact with these groups, while continuing to manage the protected district. Their recent activities include the addition of visitor-oriented facilities such as public toilets, rest areas and car parks. Since the streets in the old town are only four metres wide and car traffic would complicate its exploitation as both a living environment and a tourism asset, the local government is aiming at establishing a slow-paced tourism model, which would also increase the interaction between locals and visitors, thereby increasing the chance of local development through tourism.

\section{Consequences and Current Situation}

Interventions in built structures have focused on their visual aspects. Not only in the remaining traditional buildings, but also in the modern buildings inside the protected district, the use of elements imitating traditional architecture such as wooden lattices and plastered walls have been included in every intervention. Yet, since the combination of these built elements had not been studied, some new combinations of elements have appeared. These new combinations transform not only the external appearance of buildings, but also their functionality (Figure 4).

To avoid the occurrence of such interventions, the local government conducted new research in $2013 .{ }^{12}$ Currently, the plan includes a more comprehensive model for future interventions in buildings, linking both the façade and the interior of the house. The model also includes the use of auxiliary buildings in the rear of each plot.

Regarding the impact of tourism on local development, the area accessible to visitors is as yet limited. Only a few of the existing shop-dwellings are currently in business, while only some of the emergent buildings have been transformed into accessible facilities, such as Kamihaga house-factory, currently hosting the wax museum (Figure 5). As a result, in most of the district, the only space available for interaction between locals and visitors is limited to the four-metre-wide street. Consequently, visits to Uchiko tend to be short (on average, two hours), and tourist numbers appear inadequate to revitalise the local economy.

12. Uchiko Town, Yōkaichi Gokoku. Uchiko chō dentōteki kenzōbutsugun hozon chiku minaoshi chōsa hōkokusho (Uchiko, 2013). 


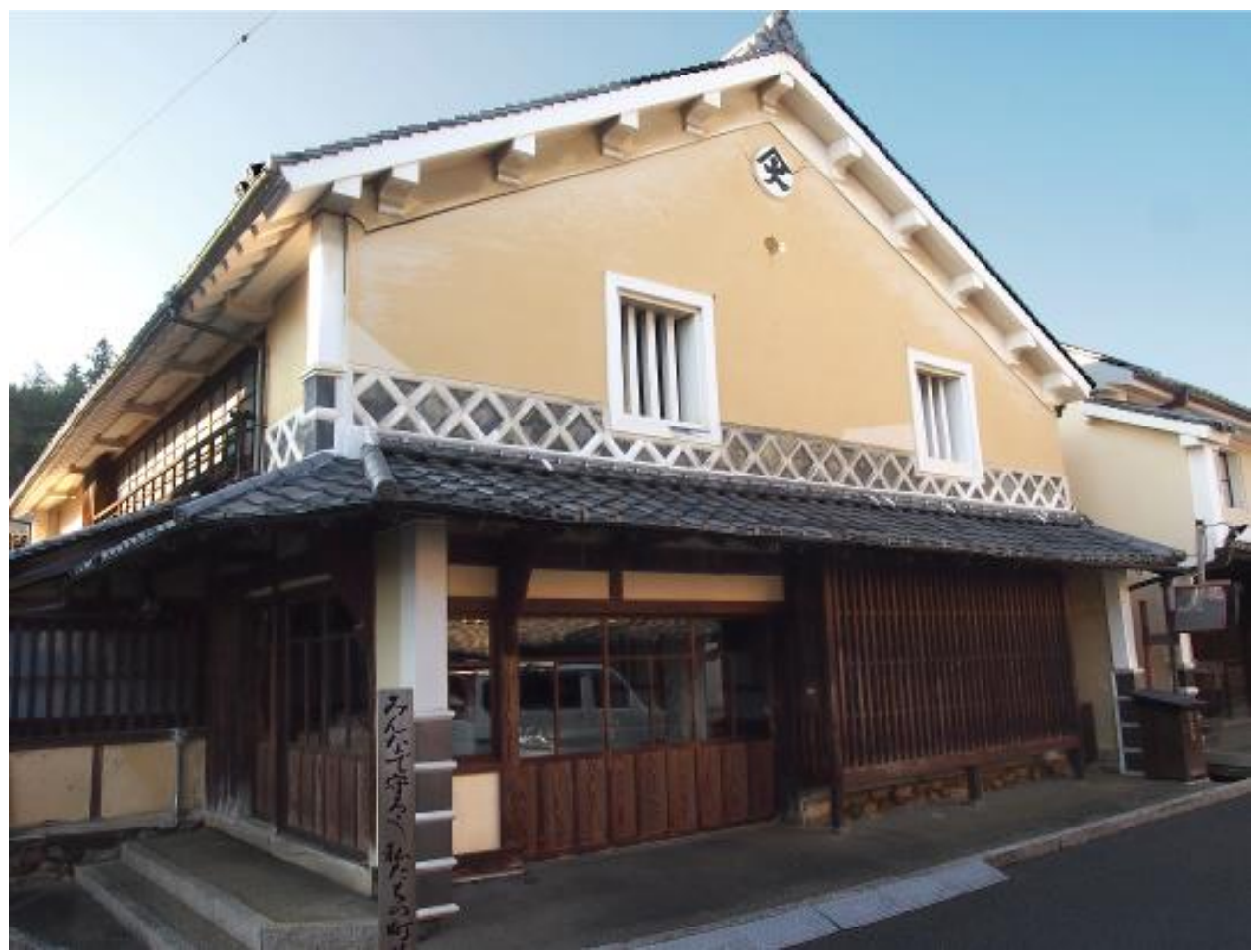

Figure 4. Façade Restored while Introducing a New Lattice, Incompatible with the Geometry of Pre-existent Pillars and Corbels Source: Author, 2015.

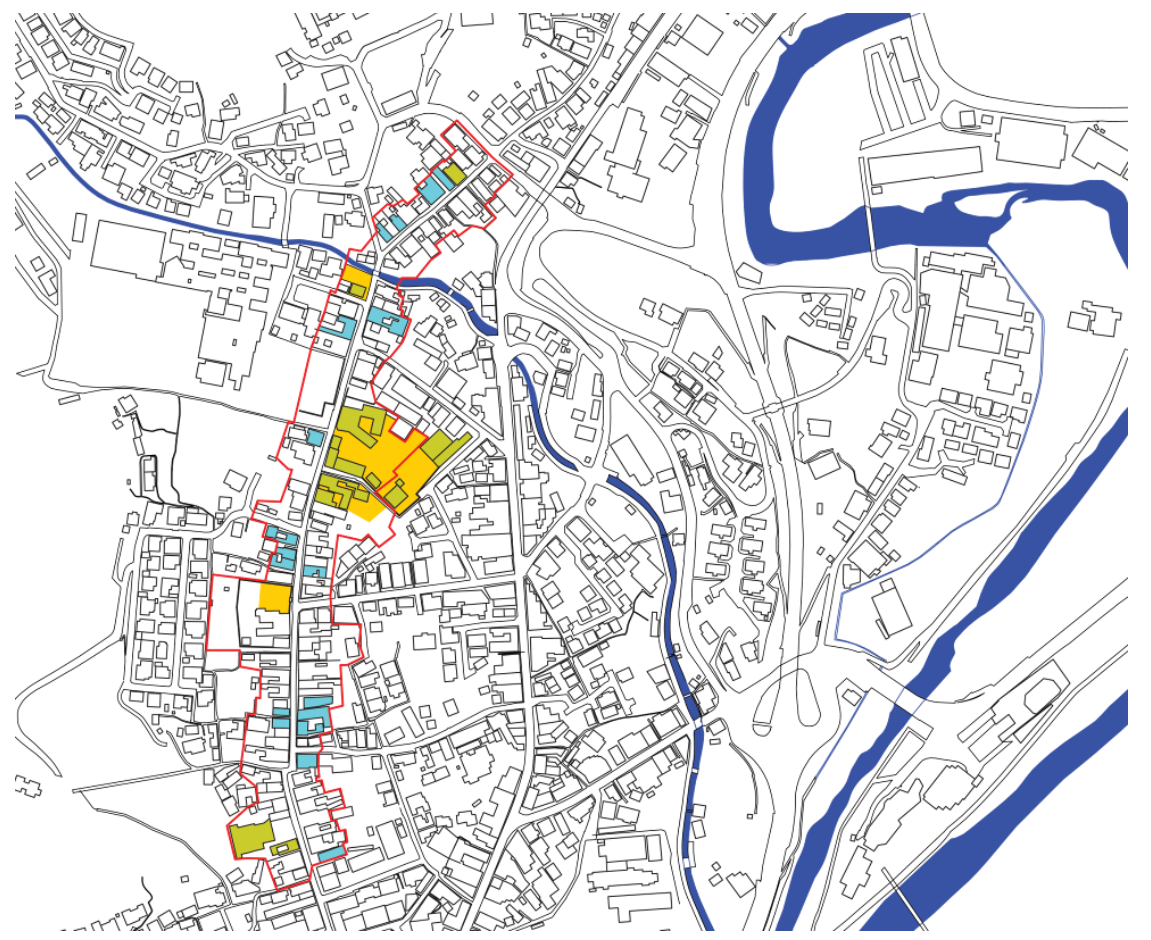

Figure 5. Uchiko, 2016. Public Facilities (green), Public Spaces (yellow) and Shops (blue) are the Few Spaces, Accessible in the Protected District Source: Drawn on map by Geospatial Information Authority of Japan, 2016. 


\section{Case Study 2, Kurayoshi (1998)}

\section{Starting Point and Motivation for Preservation Efforts}

Kurayoshi stands as an example of a district that did not fit the priorities and the valuation criteria employed in the initial stages of the denken chiku programme. By 1981, the external aspect of the buildings in the district had been altered with the addition of modern materials and built elements. Thus, its designation was rejected because it failed to satisfy the visual criteria in use at the time. However, this is not the only difference between Kurayoshi and Uchiko. Attempts to preserve Kurayoshi began as a reaction against plans by the Japanese government to enlarge the riverbed of the Tama River in order to prevent frequent flooding. The river runs the length of the old town of Kurayoshi, and its enlargement would have implied the demolition of half of the buildings in the district (Figure 6). On the other hand, the buildings proposed for demolition were mostly storehouses that were unused at the time. Thus, the motivation for the protective efforts was to preserve the living environment, which the local community was struggling to maintain, as well as revitalise the area and reclaim vacant buildings.

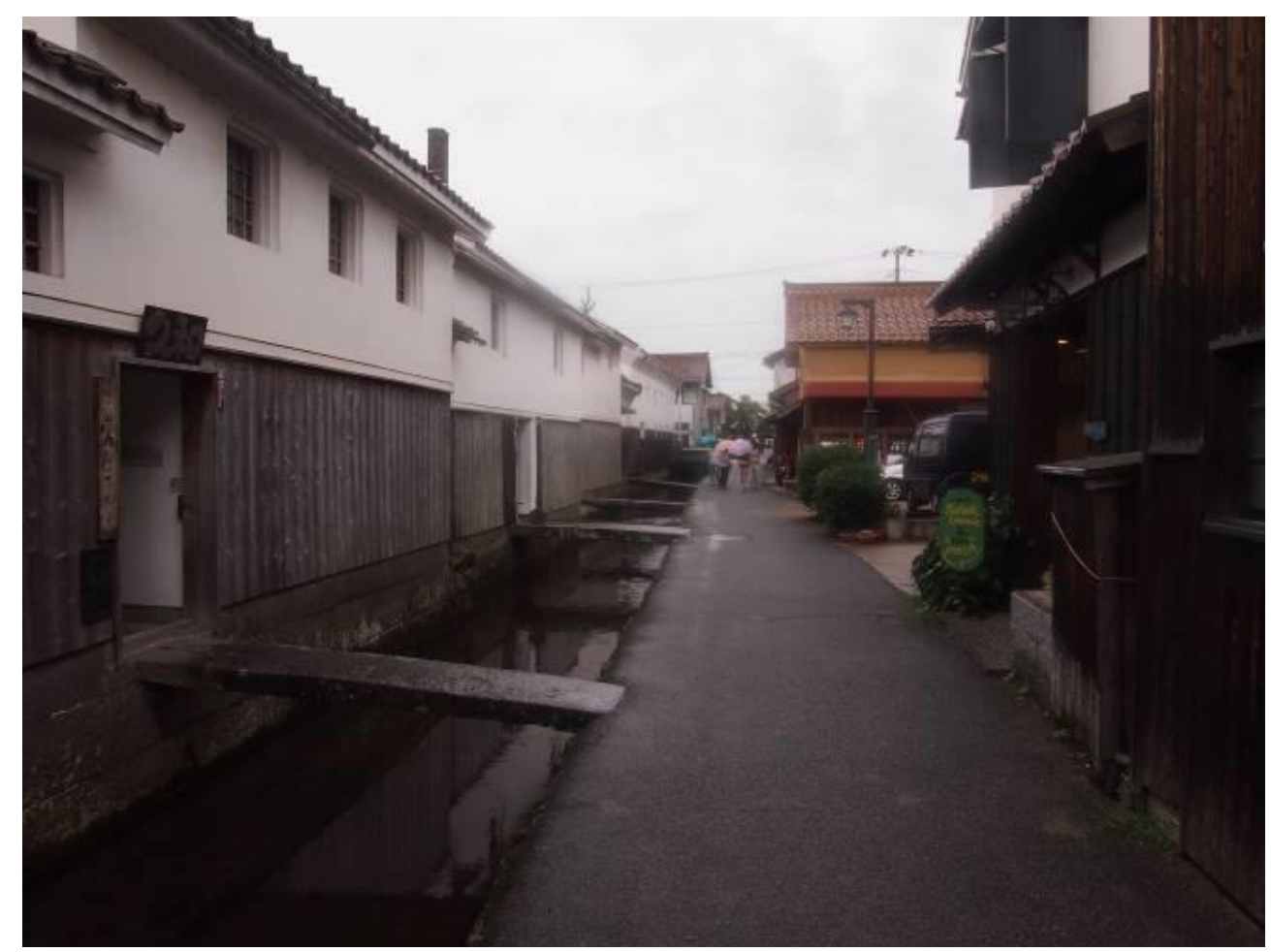

Figure 6. Kurayoshi, River and Storehouse Area Source: Author, 2016.

To understand the situation of Kurayoshi at the time, we need to understand its previous development. Kurayoshi is located in the west of Honshu island, in a basin a few kilometres from the Japan Sea. The old quarter of Kurayoshi was built in the $17^{\text {th }}$ century as a marketplace near the Tama River. Historically, 
merchants had lived on the slopes around Utsubuki Castle, but when the castle was demolished, the warriors who had been quartered there established their new dwellings on the slopes, forcing the merchants downwards, towards the river. Frequent flooding caused by the narrowness of the Tama River meant that the area nearby had been uninhabited until the forced displacement of the merchants. The new district was not only near the river, but also in close proximity to a trading route connecting the site to Tottori, Himeji and Osaka. Thus, the district served as a local marketplace, as well as a wholesale trading post for travelling merchants from major cities. The land was divided into narrow and deep plots, with front and rear façades. To the front, shopfronts were aligned to the main street. To the rear, storehouses were accessible from the river: these were not used by their owners, but rather leased by travelling merchants to store their merchandise on their way to Osaka and Himeji. Commerce on the route declined between 1900 and 1907, when the San'In railway line opened and the wholesale hubs along the old routes became obsolete. Even the local merchant activity moved from central Kurayoshi to the new district around Kurayoshi station, four kilometres to the north. A secondary railway line connected Kurayoshi station with the old town, but was shut in 1985 (Figure 7).

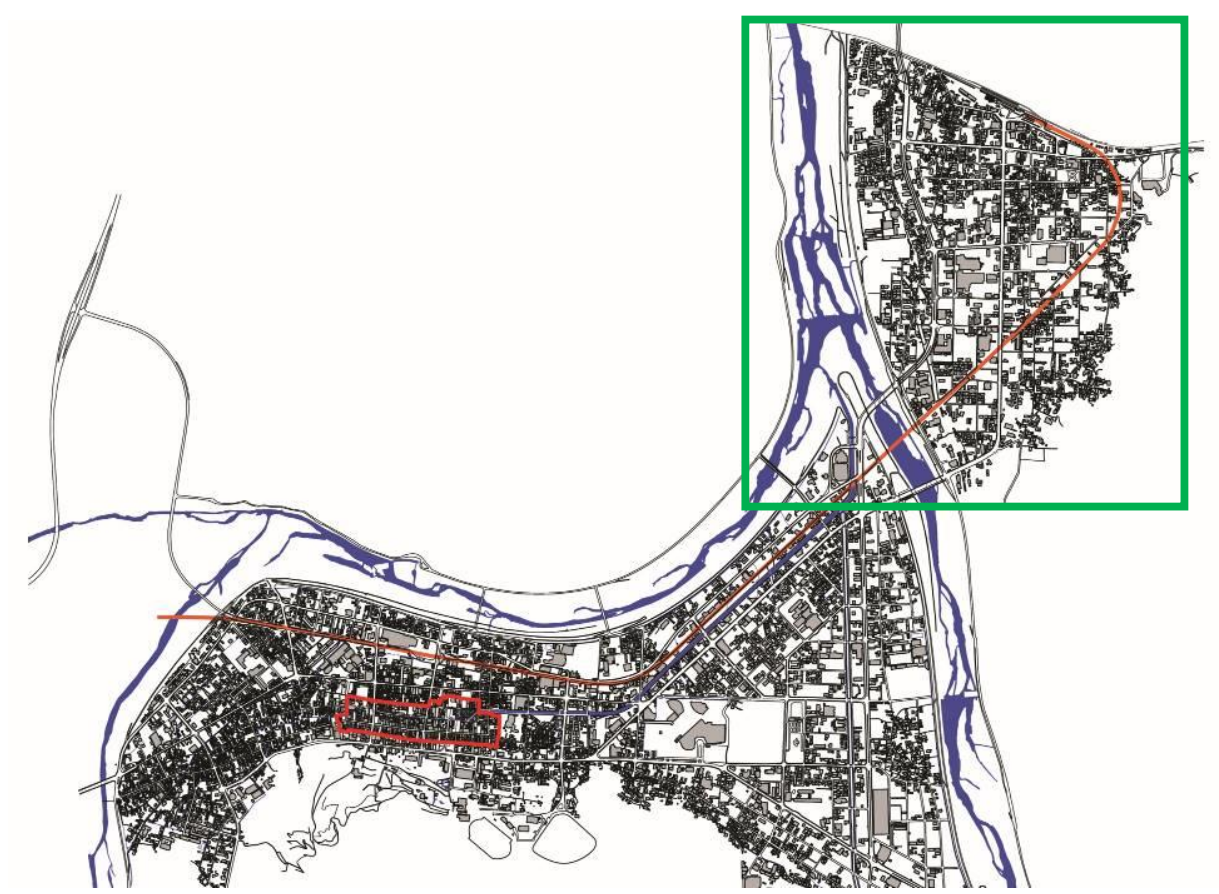

Figure 7. Plan of the Urban Area of Kurayoshi, 2016. In Red, the Current Protected Area. In Green, the New Area around JR San'In Railway Station. In Orange, the Former Kurayoshi Railway (Dismantled in 1985)

Source: Drawn on map by Geospatial Information Authority of Japan, 2016.

Throughout its history, Kurayoshi has suffered frequent floods. In 1934, the Tama riverbed was straightened and confined between stone walls in an attempt to prevent flooding. These walls were aligned to the storehouses, determining the current shape of the urban environment. In Kurayoshi, the urban environment in 
need of protection was actually built after the district's decline. Following its decay, locals made several attempts to revitalise the old quarter by adapting it to modern tastes. Thus, in the 1960s, they built a metal-and-glass arcade covering the western half of the main street, while redesigning the shop façades in a modern style. These interventions concealed, yet did not demolish, the traditional structures of Kurayoshi.

The failed attempt at attaining designation as denken chiku in 1981 was yet another of the efforts made to revitalise the old quarter. Between 1981 and its eventual designation in 1998, Kurayoshi intervened in the storehouses using its own resources. In addition, in 1982, the town was selected as a model for a study of the preservation of a merchant district in a modern residential settlement in western Tottori region. The local initiatives to preserve the quarter were still underway when the Agency for Cultural Affairs reopened the designation process in 1994. However, in 1998, only the eastern half of the district was designated as denken chiku. The western half, which had been more severely modified during the 1960s, was included in the protected perimeter in 2010.

\section{Contents of the Plan}

Kurayoshi was not as visually appealing as Uchiko, due to the interventions in the 1960s (Figure 8). Yet, the structures inside each plot of land remained unaltered. Thus, the plan, ${ }^{13}$ which was based on the same study conducted for the 1981 designation attempt, ${ }^{14}$ did not limit its reach to the buildings facing the main street, but included the whole land plot structure and internal organisation. Each type of building (houses, storehouses, reception rooms for customers) was analysed in its location inside each plot. Moreover, their accessibility from outside, through bridges on the river area, was included in the protected elements (Figure 9).

13. Kurayoshi City, Kurayoshi shi Utsubuki Tamagawa dentōteki kenzōbutsugun hozon chiku hozon keikaku (Kurayoshi, 2001).

14. Kurayoshi City, Kurayoshi shōka machinami taisaku chōsa hōkokusho (Kurayoshi, 1980). 


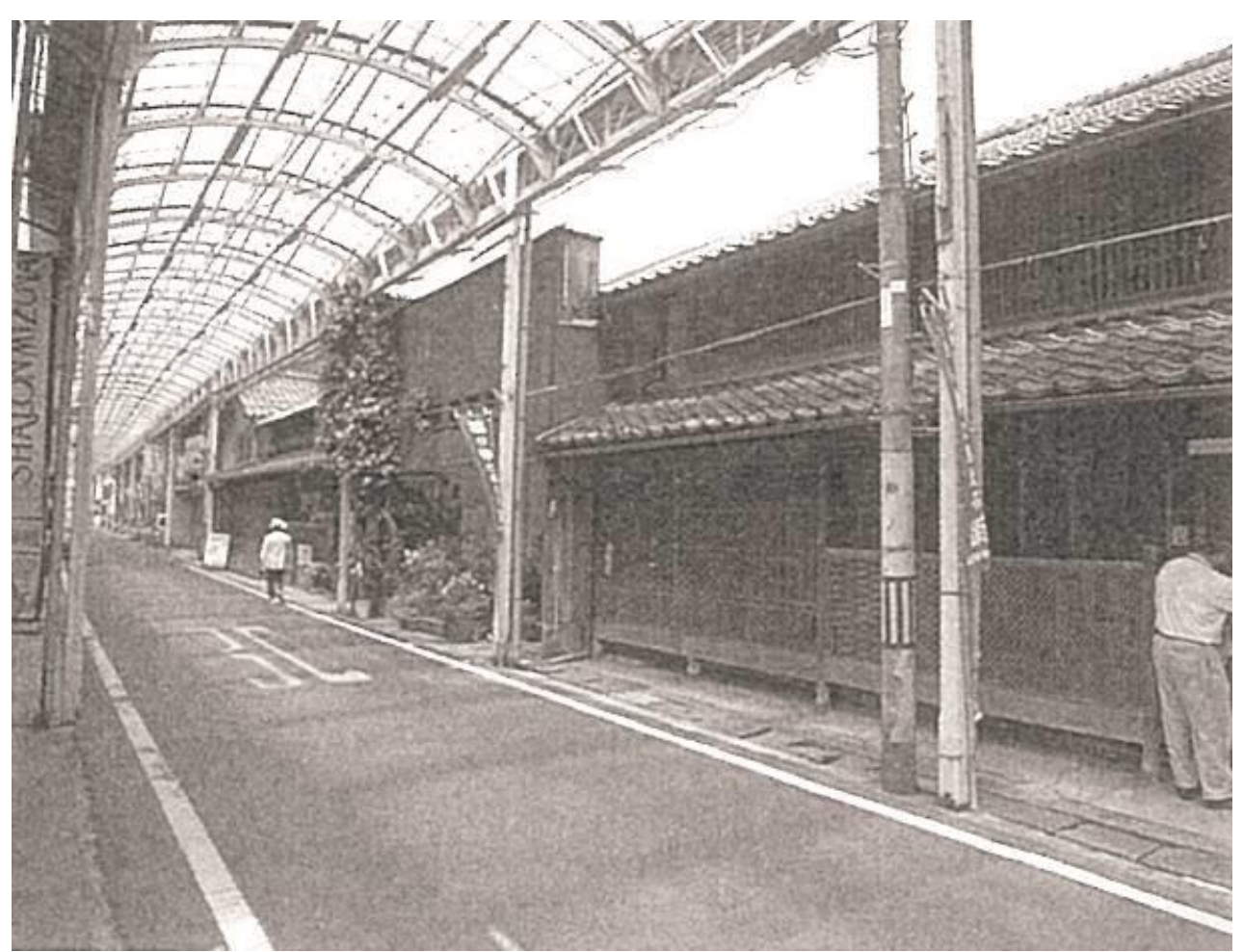

Figure 8. Kurayoshi, Arcade Built in the 1960s

Source: Kurayoshi Board of Education, 1980.

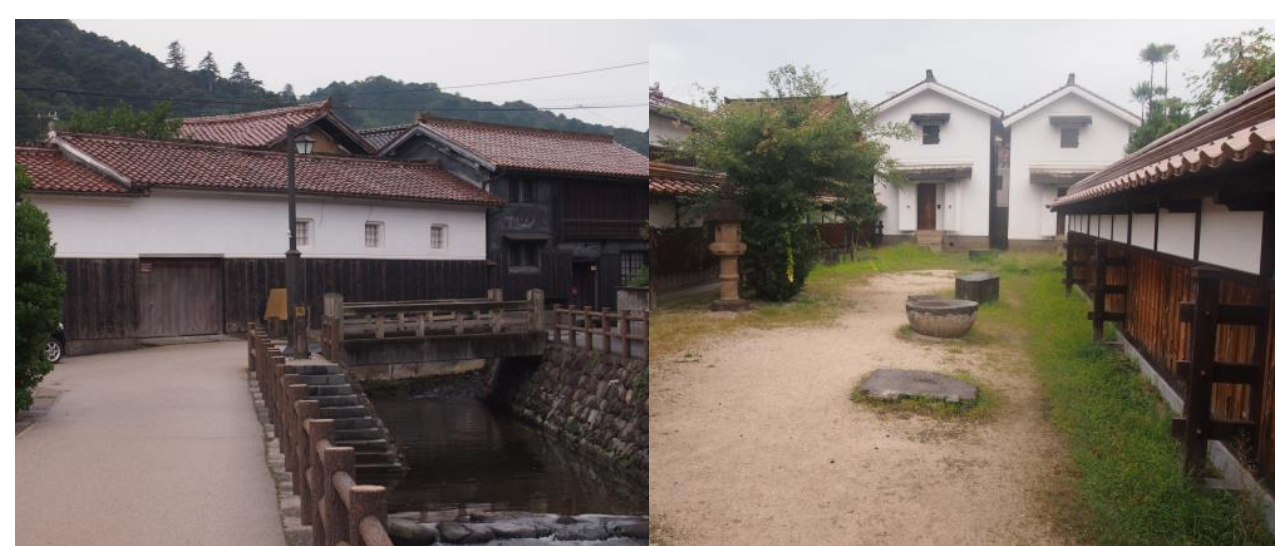

Figure 9. Kurayoshi, Built Types: Rear Storehouse and Reception Room with Access from the River, and Interior of a Courtyard inside a Private Land Plot Source: Author, 2016.

As for temporal criteria, Kurayoshi did not define a prime time period as a reference point for interventions, since the urban landscape to protect contained significant elements dating from after the location's heyday. Thus, buildings were studied by dating them and their built elements, rather than ascribing them to specific typologies. In a later survey, conducted in 2009, the dating would be extended to the individual components of each building, thus creating an understanding of the superposition of the different temporal layers existing in each 
building through a chrono-typology method. ${ }^{15}$ The appearance of new elements in the façade and the internal structure was then linked to the evolution of the use of each room in the building: roof structures that had been raised to host new rooms in a newly built mezzanine, or new types of lattices designed to reveal and conceal different areas of the shops (Figure 10).

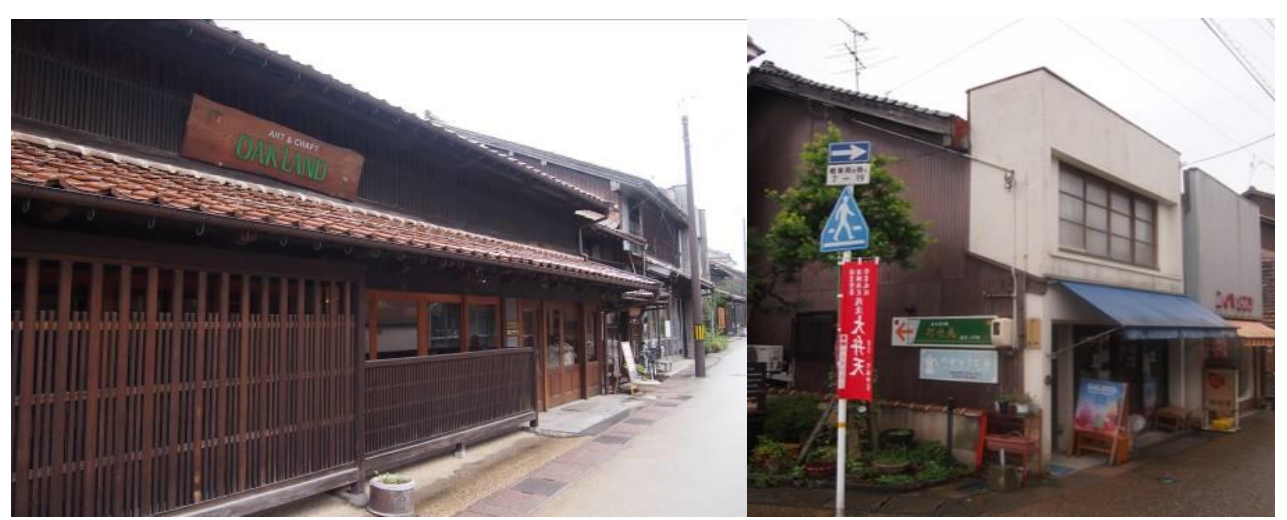

Figure 10. Relation between Different Elements with Interior Spaces

Source: Author, 2016.

Regarding the implementation of the plan in preservation works, the plan required the conduct of historical research on all building subject to such works. In doing so, knowledge about the evolution of Kurayoshi became more detailed, which bolstered the historical accuracy of the preservation works.

\section{Management Model}

The management model in Kurayoshi requires coordination between local government, community and merchants. All three participate in the protection council, which establishes the criteria for protection of the district. They also debate any proposed activity for the revitalisation of the district, such as festivals or advertising campaigns.

Local government is responsible for historical research on preservation works, as well as contact with the Agency for Cultural Affairs. They are also in charge of the preservation of public services such as water channels and streets, and safety equipment such as fire alarms. The community, represented by the Association for the Preservation of Kurayoshi, focuses its activities on raising awareness regarding protection of the townscape and the prevention of disasters. After refurbishing a plot of land and the buildings thereon in their entirety, they created the Kurayōshin Community and Fire Prevention Centre, in which all of their safety equipment is stored. They also organise periodic drills to train locals in the use of the equipment for firefighting.

As for the local merchants, their activities focus on the revitalisation of the economic activity inside the district. They founded a company named Akagawara (literally 'red tile', in reference to the red roof tiles typically used throughout the

15. Kurayoshi City, Kurayoshi shi Utsubuki Tamagawa dentōteki kenzōbutsugun hozon chiku minaoshi chōsa hōkokusho (Kurayoshi, 2009). 
district), which leases unused buildings. These buildings are used for a variety of businesses, in which tourism is, at most, a complementary activity. Among the facilities opened by Akagawara, there is one, the Wakamono Ikiiki Cafe, that serves as a meeting point for young locals, an information centre for people interested in establishing a permanent business to service local needs, and a tourism information point. In doing so, they expect to ensure the existence of the next generation that will keep the district alive.

\section{Consequences and Current Situation}

The results of these interventions are not limited to the cosmetic, but have deeper structural implications. While the visual aspects are a prerequisite within the denken chiku network, Kurayoshi focused on the structural preservation of the buildings, in addition to any other fixtures uncovered during the renovations. Old lattices and façade elements have been restored in those cases where some remains could be found; yet, the elements completed as part of the interventions are distinguishable from the old pieces (Figure 11).

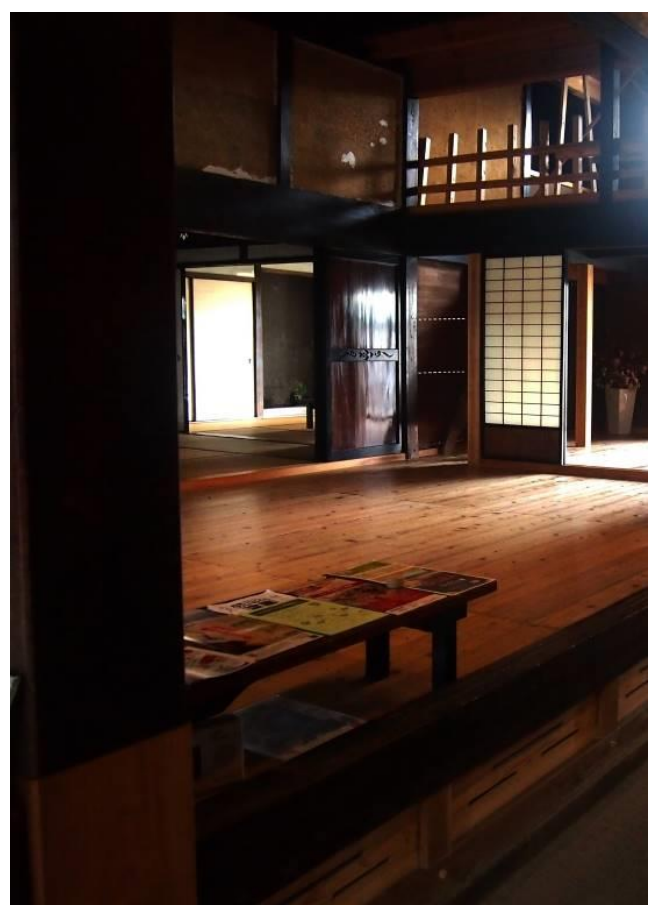

Figure 11. Intervention with Old and New Elements in Different Colours Source: Author, 2016.

The works also focused on the structures on each plot of land, including the outbuildings, open spaces and access networks. Provided that storehouses have their own access from the street, they can be used independently from the main houses on each plot of land. Thus, some storehouses have been repurposed for the establishment of new businesses. Consequently, new businesses have been opened in buildings that are not meant to host a dwelling. According to surveys undertaken by the local government, these buildings are used only during the day, 
and do not present an opportunity to increase the number of people resident in the district; nevertheless, previously unused buildings are still being recovered.

These repurposed buildings, combined with the buildings leased by Akagawara, have revitalised the area, particularly the eastern part of the district (Figure 12). The facilities launched by the local community are also open and in use, contributing to the area's reinvigoration. At present, Kurayoshi's old district is still centrally located in relation to public facilities, with schools, hospitals, courts and local government buildings all within walking distance. In the future, the revitalisation is likely to extend to the western area of the district, which holds similar potential for residential and commercial activity, despite its more recent inclusion in the protected district.

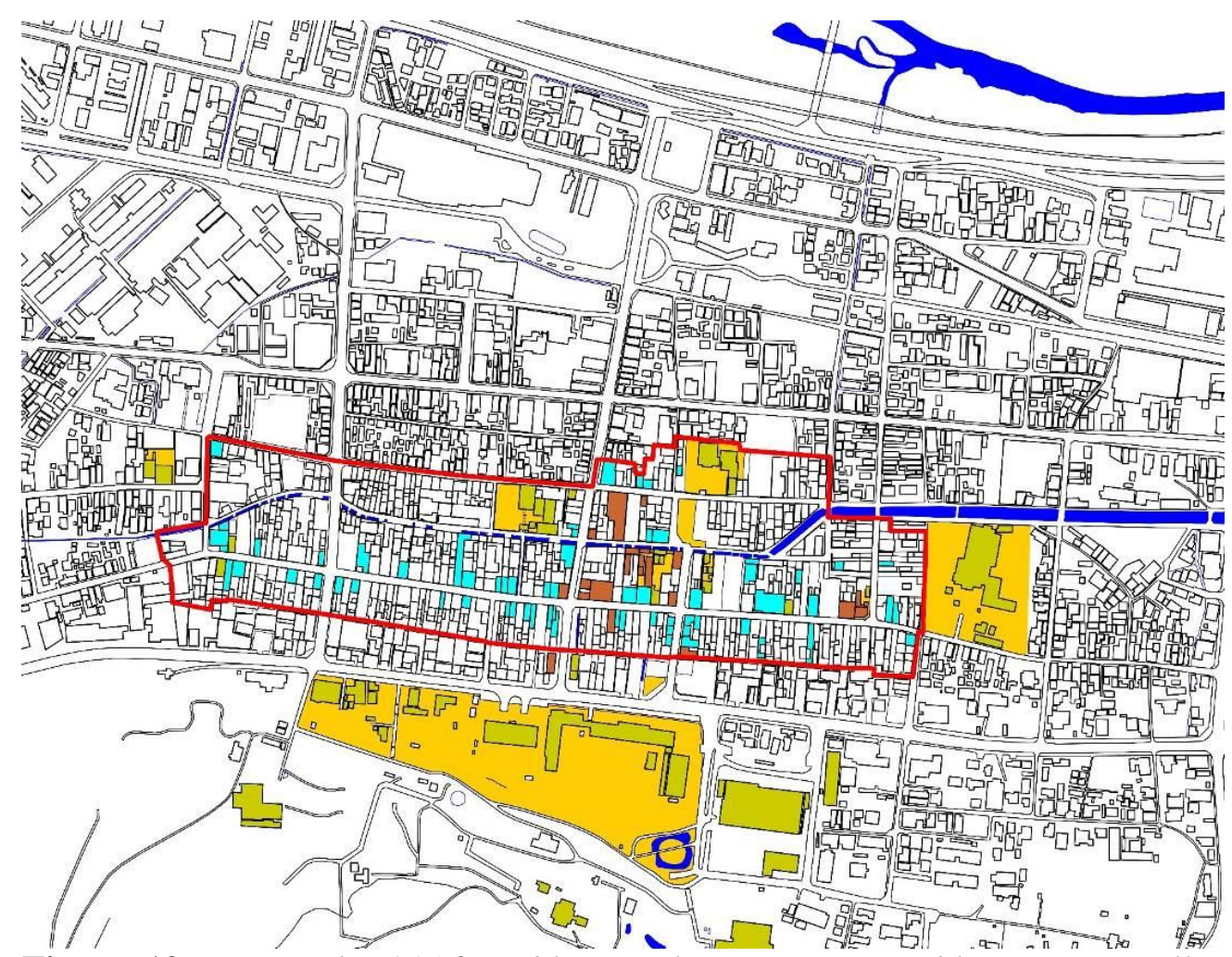

Figure 12. Kurayoshi, 2016. Public Facilities (green), Public Spaces (yellow), Shops (blue), plus the Buildings Repurposed by Akagawara (red)

Source: Drawn on map by Geospatial Information Authority of Japan, 2016.

\section{Case Study 3, Ine (2004-05)}

\section{Starting Point and Motivation for Preservation Efforts}

Ine was the first district designated after the passing of the 2004 Landscape Law. The law was the culmination of a progressive valuation of the landscape, 
which had started in the 1930s in Kyoto, ${ }^{16}$ but accelerated in the 1990 s as a consequence of a series of events leading to the international acknowledgement of Japanese heritage and landscape. By the time the gasshözukuri villages of Ainokura, Suganuma and Shirakawa-gō were included in UNESCO World Heritage List, Japanologist Alex Kerr published the original Japanese version of his award-winning book, Lost Japan, ${ }^{17}$ about the disappearance of the Japanese culture and landscape. Even the Japanese government became aware of the extent to which the Japanese landscape had been ruined, even in rural areas, during the pre-1990 asset price bubble. In 2003, the Japanese government passed the Fundamental Policy Principles to Make a Beautiful Country, which was aimed at valuing traditional landscapes and reversing the damage caused by economic development. Thus, the first protected districts that included landscape elements appeared immediately following the passing of the Landscape Law.

Ine is located in a natural harbour and enjoys a rich ecosystem of forests and ocean, which is home to several varieties of fish. Fishing activity and the exploitation of natural resources precipitated the development of the town between the $15^{\text {th }}$ and $17^{\text {th }}$ centuries. The harbour was also used as a haven for cargo ships from the early $17^{\text {th }}$ century, which allowed locals to produce and sell products sake and grains - to the ships' crews. The hilly geography of Ine made access to the village easier by boat than overland. In fact, Ine was divided into three communities, and even moving from one community to another was easier by boat (Figure 13). A road running the coastline and linking all three communities was completed in 1954. However, since the settlements were established in a narrow strip of land between the hills and the sea, the available space on which to build the road was limited. The only solution was to set the course of the road through the middle of the plots of land, thereby splitting every property in two. Still, the resultant road was narrow, being three metres wide in some places, and consequently difficult to access for public transportation. Studies from the late 1970s and early 1980s still described Ine as being more easily accessible by boat than by bus. ${ }^{18}$

16. G. Nitschke, "Protection of urban place of Kyoto," in Hozon: Architectural and urban conservation in Japan (ed.) Siegfried RCT Enders and Niels Gutschow (Stuttgart/London: Edition Axel Menges, 1998).

17. A. Kerr, Utsukushiki Nihon no zanzō (Tokyo: Shinchosha, 1993).

18. T. Myojo, "Funayatai no mawari butai ni tsuite. Kyōto fu Yosa gun Ine chō tairyō matsuri," in Nihon engeki gakkai kiyō, no. 12 (March 1971), 48-55; S. Matsumoto, "Gyogyō shūraku ni okeru kōtsū seikatsu. Kyōto fu Ine chō ni okeru kesu sutadi," in Toshi keikaku ronbunshū, no. 15 (November 1980). 


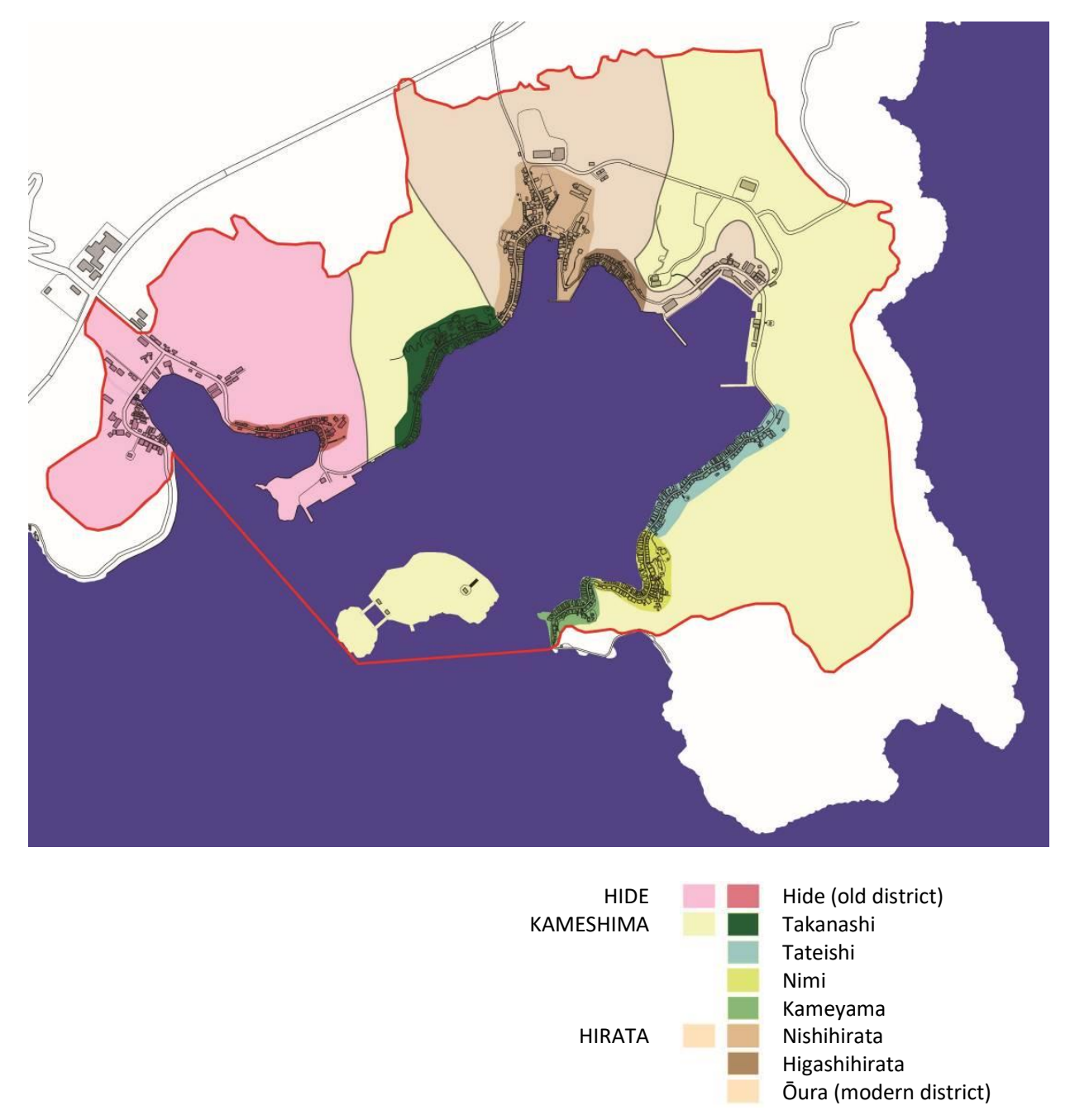

Figure 13. Three Communities and their Subdivisions, Ine Village Source: Drawn on map by Geospatial Information Authority of Japan, 2017.

Efforts to conserve Ine began in 1975, when local fishermen saw their living environment being threatened by the construction of infrastructure. The government proposed the construction of a thermal power station a few kilometres from the village. The plant would have raised the temperature of the surrounding sea, threatening the ecosystem and consequently the livelihoods of the local fishermen. Furthermore, the large-scale fishing industry, introduced to Ine in the 1950s, was in decline following the oil crisis of 1973. Consequently, local fishermen started recovering the traditional, small-scale fishing techniques of earlier years. Thus, the starting point for the conservation of Ine rested on two pillars: the protection of the environment and the recovery of immaterial heritage (i.e. knowledge developed for the exploitation of the environment). When Ine was designed denken chiku, it was therefore unsurprising that the protection perimeter was significantly larger than that of most previously designated denken chiku, which included the whole environment, including the sea inside the harbour. 


\section{Contents of the Plan}

The first element that the survey ${ }^{19}$ and the subsequent protection plan ${ }^{20}$ took into consideration was the environment, as well as its link to the settlement. The fishing techniques developed while taking advantage of the conditions of the harbour were described as a generator of the urban shape. The fishermen used to fish in groups of small boats, while cornering their catches. These boats, which would rot if left outside, needed a structure for their protection. The funaya were created for that purpose. These were small boathouses, built to host one or two small boats, as well as the tools needed for fishing. Being built on the coastline, they were also the urban façade of Ine when it was accessed by boat. The dwellings, which were built behind the funaya, became separated from the funaya when the road bisected the properties. As long as transportation by boat was in use, the funaya were also the points of access to the dwellings. In this context, the plan considered the funaya as the element linking the environment, the fishing industry and the local community together (Figure 14).

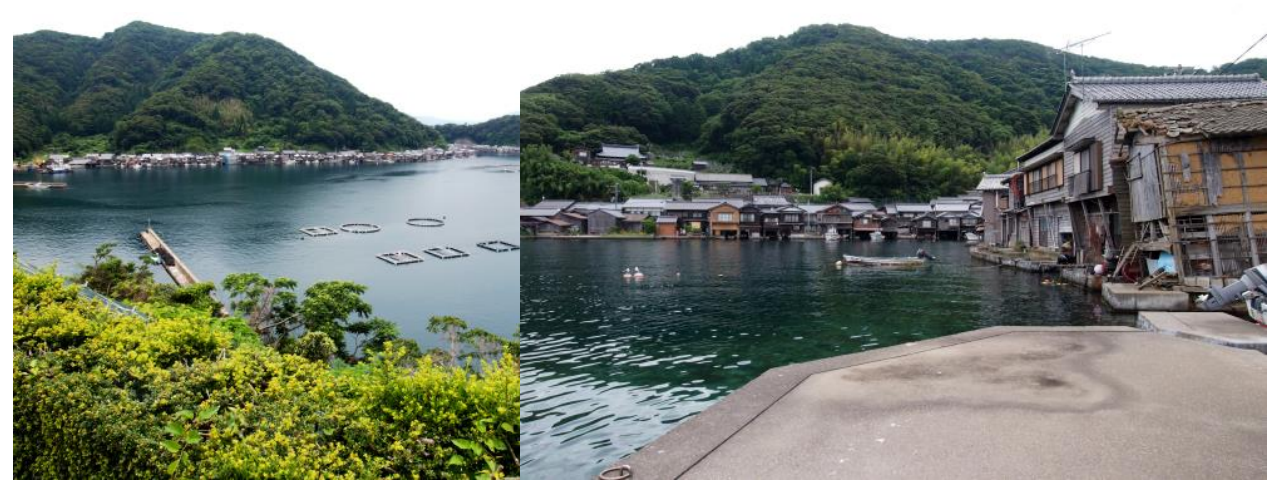

Figure 14. Ine, its Protected Landscape and View of the Funaya

Source: Author, 2016.

In 2004, the funaya were literally sinking. Several had been repurposed as dwellings or garages, thus adding extra weight to their light wooden structures. In addition, the foundations had suffered severe damage from the uncontrolled sewage emanating from dwellings, as well as from sanitary facilities often built in the funaya. The plan studied each funaya and classified them according to the degree of transformation from their original state as boathouses. A significant degree of transformation would have different implications from a significant degree of preservation, since the use of the structure, its accessibility (from both sea and land) and its links to the environment were different. Some of them still worked as an entrance gate to the house from the bay, while others had lost any contact with the bay as a public space (Figure 15). The implications for the use of space and the production and reproduction of social relations in the spaces were remarkable.

19. Ine Town, Ine Ura dentōteki kenzōbutsugun hozon taisaku chōsa hōkokusho (Ine, 2004); Ine Town, Ine Ura dentōteki kenzōbutsugun hozon taisaku chōsa hōkokusho gaiyōhan (Ine, 2005).

20. Ine Town, Ine chō dentōteki kenzōbutsugun hozon chiku hozon keikaku (Ine, 2005). 

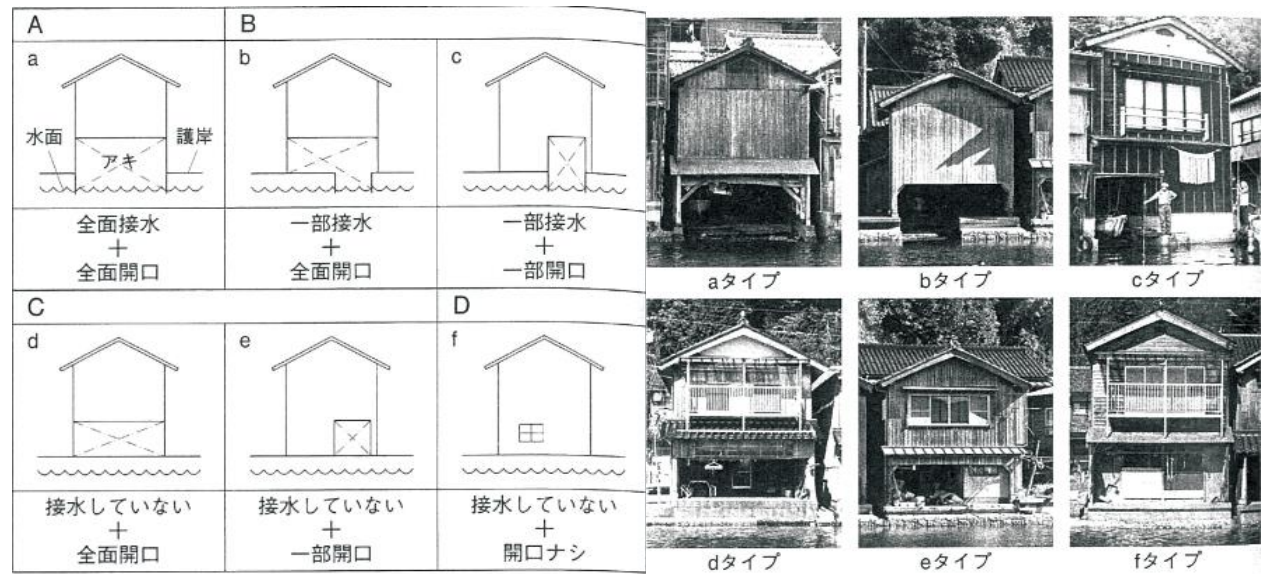

Figure 15. Classification of the Funaya based on their Current Situation Source: Ine Board of Education, 2004.

The analysis of the urban structures also focused on the changes that the building of the modern road had brought to the use of the space, and the links between the road and the pre-existent spaces in which social encounters had occurred. The road had been opened through a central space, which was a common domestic space for each community. Before that, these central spaces were not connected to the central spaces of other communities; instead, access was gained through the sea or the mountains above. In that context, the central space was a common yard in which to perform everyday domestic activities related to fishing (e.g., fixing fishing nets or processing various products such as dry seaweed) or everyday trading and social relations. Houses used to have a bench out front on which products were displayed for sale; some houses retain this feature. However, these types of small structures were necessarily intended for small-scale trading (Figure 16).

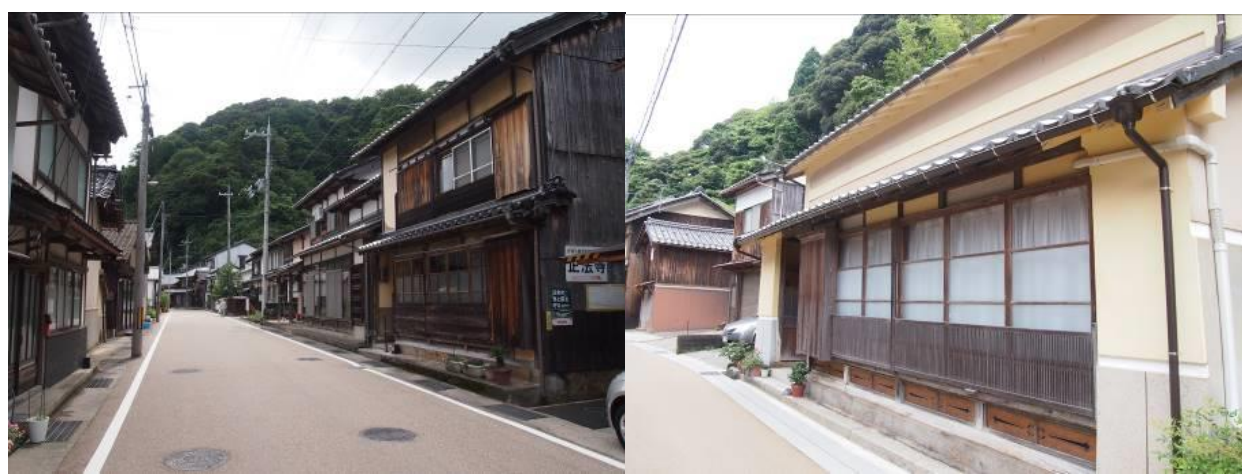

Figure 16. Central Road (Former Backyard) and Detail of a Façade with a Display to Sell Products

Source: Author, 2016.

The central space had been connected to the sea through disembarkation points between the funaya. These disembarkation points, or butai (the same word used in Japanese for theatre stages, such as in kabuki theatre), were mainly used for events and ceremonies involving people from inside and outside the 
community (visits, festivals, weddings, etc.). At the same time, these butai were directly connected to the paths and stairways leading to the temples and shrines uphill. These temples and shrines were at the same time landmarks in the network of pedestrian paths that linked each community to the others by land (Figure 17).

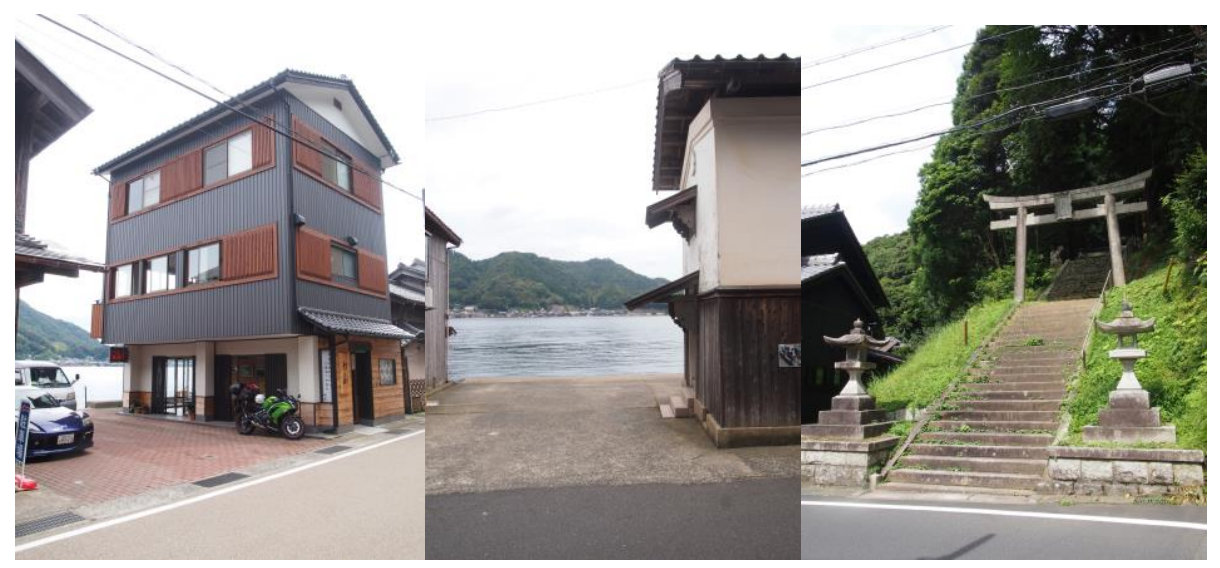

Figure 17. Two Butai in their Current State, and Access Path to a Shrine Source: Author, 2016.

In this context, the preservation plan previewed the preservation of any environmental element that composed any of these spaces: stairs leading to temples and shrines, stone walls lining the sides of the old pedestrian paths, gates and spaces in front of temples and shrines, and docks at disembarkation points. However, they were defined as the material parts to be preserved, while other aspects, such as the use of these spaces, were not regulated.

Finally, the plan included a study of the structure of land property. The construction of the road had split most of the properties in two, with the main house on the hillside and the funaya on the seaside. Other buildings such as storehouses were either located next to the main house, next to the funaya, or grouped in places next to the land where cultivated fields used to be. The study concluded that most of the structure of property had remained unaltered, with each funaya typically remaining the property of the house directly behind it. This would be taken into consideration when solving problems such as uncontrolled sewage emanating from each house.

\section{Management Model}

The management model in Ine was centred in the local council, originally founded by local fishermen. They had organised themselves to recover and preserve their traditional techniques, and to lobby against the works threatening their environment. The preservation of the immaterial part of their heritage remains their job. They have also rethought the use of the abandoned boathouses, which are often converted into dwellings for their relatives, or occasionally into lodgings for tourists. Other tasks related to immaterial culture, such as the Ine festival, which takes place every year in early August, are also performed by local people. The government used to take a support role: due to the lack of 
professionals (carpenters, designers, historians), the preservation works were frequently performed under the initiative of locals, who were often unaware of the difficulties inherent in performing such tasks in accordance with the directions provided by the Agency for Cultural Affairs. The local government therefore produced a handbook containing directions for preservation works and a catalogue of the traditional designs of built elements to be used as a reference. ${ }^{21}$ The local government is also responsible for the preservation of urban elements such as paths, walls and stairs.

The management model in Ine is currently facing difficulties. According to the local government, Ine tops the list of villages with the most elderly, singleperson households in Japan. Consequently, the local association, created in 1993, is in a predicament as no new generation is available to take over from the previous one. The local council is becoming inactive due to the lack of members, making the local government to take over some tasks for which the local council was responsible. The contact office of the local council is currently the municipal board of education.

\section{Consequences and Current Situation}

Given the focus of both the local government's plan and tasks on the environment, most of the visible results of the preservation works are in relation to the environmental elements and infrastructure required to preserve them. Walls, stairs and paths were preserved or even recovered, while fire safety infrastructure and sewage systems were implemented. The unaltered structure of property facilitated the installation of individual sewage collectors in each house, of which the vents are visible from the central road.

Buildings have been treated more loosely. Most of the interventions were performed by locals, and the local government only regulated the volume thereof, or the possible addition of floors or new annexes. As long as the overall appearance of the environment was not altered, the government only based its activity on the recommendations in the handbook. Consequently, some of the houses preserved their traditional fixtures, such as windows, or the benches intended for small-scale trading, which also function as small lattices when unused, while other houses replaced those elements with modern materials that satisfy the same needs, for instance, by replacing the lattices with translucid glass to increase the privacy of the interior.

Regarding urban systems, car traffic in Ine is conflictive, especially in the eastern quarter. The road there is at some points as narrow as three metres. This makes the road in the east impracticable for interurban buses, leaving only the possibility of using vans or microbuses for local public transportation. Consequently, the eastern quarters of the village have higher concentrations of funaya that have been transformed into car parks (Figure 18). As for public parking lots, most of them are concentrated in the central districts, but some of them occupy the locations of former public facilities. These facilities were moved to other land plots outside the district. As a result, the current inhabitants in the far-

21. Ine Town, Machizukuri no tebiki (Ine, 2012). 
eastern area of Ine bay must walk six kilometres to reach the municipal offices or the public health centre, while public transportation is often unavailable.

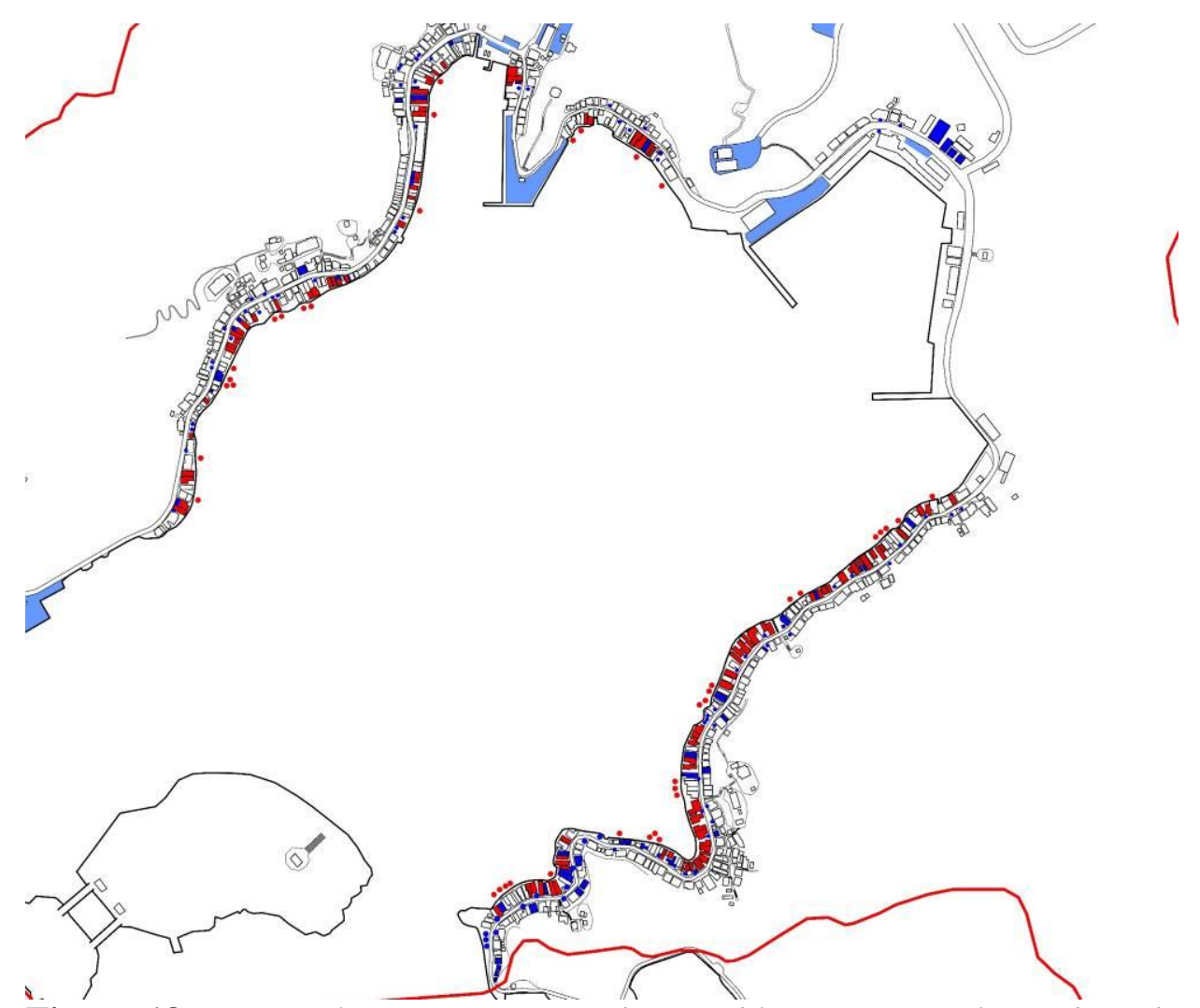

Figure 18. Car Parks on Private Land (navy blue), Boat Parks (red) and Public Car Parks (light blue)

Source: Drawn on map by Geospatial Information Authority of Japan, 2017.

Likewise, local businesses are concentrated in the central and western areas of Ine, using for that purpose both former houses and funaya. Thus, the unaltered funaya, which preserve their entrance from the sea, are concentrated in the eastern part. The significance of the seaside as the once so-called 'façade of Ine' differs depending on the zone of Ine: some areas of this seaside front, especially in the central and western areas, are not accessible by any means whatsoever, including sea or land. The lack of definition in the use of the former butai caused these disembarkation points to be transformed to varying degrees: while some are still accessible, others are used as private land or even host annexes such as garages.

\section{Discussion and Analysis of Results}

The three studied approaches exhibit different valuation systems and management models, which have led to a diversity of results in the preservation of urban structures and spaces.

The case of Uchiko was developed in the above-defined stage 1. In this stage, the denken chiku system was still to be comprehensively defined, and local 
communities' degree of awareness of their built environment was still low. Even in the towns that set the example for the protected districts to come, strong leadership by some local public workers was necessary to develop the protection plan, often in the face of resistance from the local inhabitants. ${ }^{22}$ In some cases, the initiative for protection came from scholars who lacked any direct relations with the local government, ${ }^{23}$ while only in exceptional cases, such as the current UNESCO World Heritage Site of Shirakawa-gō, the initiative came from the local inhabitants. ${ }^{24}$ Either way, tourism was seen as a tool for local redevelopment, especially - but not only - in areas accessible by train. Moreover, tourism would ideally bring an external valuation of protected districts, which would help increase the awareness of this valuation among locals. That concept was the starting point expressed by Fumiyoshi Okada, founder of the Uchiko Townscape Protection Centre (in Japanese, Uchiko Machinami Hozon Sentaa), in every interview. ${ }^{25}$ Thus, even in the districts most difficult for tourists to access, tourism was considered when determining the protection plan.

In this stage, districts would try to use their heritage as a tourism asset, while improving the standards of living and the awareness within the community. However, the protection plans at these initial stages concentrated on the visual aspects of the streetscapes, while the interior of the structures was neither thoroughly researched nor regulated. Consequently, the space truly available for tourism is typically limited to the street itself, in addition to a few public buildings. The tourism assets in central Uchiko appear insufficient to generate the critical mass required to encourage tourists to stay in the town. From this perspective, Uchiko's greatest achievement is involving locals from the rural quarters inside the municipality to create a comprehensive network of available places and assets. This network is also proof of the effective growth of awareness in Uchiko, and widens the scope of the protection model to rural quarters and their resources. The evolution of the local government approach towards a more comprehensive model of interventions in dwellings, considering both their interiors and exteriors, seems a step towards solving the problems created by the tourism-oriented model.

In contrast, Kurayoshi has incorporated the study of both the interiors and exteriors of built structures since the beginning of its conservation efforts. In stage 2 , tourism was not the main goal in new protected districts, but at most a supporting activity for the local economic activity. Instead, the town's depopulation and the decline of the local economy, which was also responsible for many structures standing unused, were the main concerns. Thus, protection through use was the main driver in Kurayoshi. This focus resulted in several unused buildings being put to fresh use by new merchants and professionals. In addition, in order to

22. Nishimura, Shögen. Machinami hozon, 2007. This was the case of districts that are among the first-designated denken chiku, such as Tsumago (designated in 1976).

23. As an example of this external scholarly activity, the case of Fukiya district is worth mentioning: see Nariwa Town, Board of Education, Bicchu Fukiya: machinami chōsa hōkokusho (Nariwa, 1977).

24. S. Seizawa, "Sekai isan no hozon to katsuyō wo sasaeru shakaiteki nettowāku. Gifu ken Shirakawa mura to Betonamu Hoian no jirei kara," in Bulletin of Research Institute 14 (2006), 75-95.

25. Nishimura, Shōgen. Machinami hozon, 2007; M. Mori, Hankotsu no kōmuin machi wo migaku: Uchiko chō Okada Fumiyoshi no machinami muranami hozon (Tokyo: Akishobō, 2014) 
make the unused buildings accessible, the central gardens of some plots of land were opened to the public. As a side-effect, the spaces accessible to tourists have increased. In addition, Kurayoshi presents a great achievement when compared with stage 1 districts, namely the involvement of the local community in the management model. Given the main goal of protective efforts - to improve the living environment for locals - and the fact that, by the time Kurayoshi was designated as denken chiku, the degree of awareness about the denken chiku system was higher, the involvement of the local community was achieved faster. Nevertheless, given that most of the repurposed buildings were not prepared to be dwellings, their impact on the depopulation of the local community has been negligible.

As for Ine, the use of many structures, especially the funaya, had already been altered to provide solutions to new needs: parking spaces, extra dwelling space for smaller family units, or businesses. The local community had already adapted their space, thus continuing their life as a community. In stage 3 , with the inclusion of cultural landscapes as elements to protect, the number of districts in rural landscapes has increased. These rural landscapes host communities that have not been altered to the same extent as those in urban areas. In this context, Ine is a case with a well-defined fishing community that took the initiative for protection by themselves. The community viewpoint allows the preservation process to consider the landscape not only in visual terms, but also in terms of the network of resources necessary for local life. This is at the same time compatible with the valuation of rural areas and their resources seen in the case of Uchiko. The tendency is towards a concept of preservation that is more comprehensive, as regards both protected elements and systems, and more inclusive, as regards participating actors. The results are also more visible in the interventions, in which the exclusively visual aspects of the streetscape have evolved to compose structural and environmental aspects of the whole settlement.

However, Ine is by no means a district with all its problems solved. First, the population is still in decline, despite the revitalisation of the local fishing industry. Second, the meaning of the inclusion of spaces such as the bay area inside the protected perimeter is not clear. What currently constitutes the façade of Ine? The way in which visitors access each property was altered by the opening of the road. Many buildings now have no access to the bay, which once was the main space for mobility inside Ine. As for the road, it still occupies the central yards of the old land plots, and its visual link with the bay is often limited to the remaining butai. The use of the butai themselves, most of which are no longer used as disembarkation points, is unclear. The current use of funaya as garages also influences the state of the road, in which pedestrians and vehicles share space. Meanwhile, the unused state of the disembarkation points, along with the removal of access for boats in several funaya, could be an opportunity to recover the seafront through the creation of itineraries and spaces for pedestrians along the seafront, which could at the same time, recover the bay as a principal urban space. 


\section{Conclusions}

The three case studies outlined above are examples of the three stages of the national policies on preservation defined in the introduction of this paper. As we have seen when relating each case with the stage in which it was inscribed, the valuation system at a national level has evolved in line with the management models applied locally by each municipal government. Thus, as the valuation system shifted from tourism-centred to living environment-centred (i.e., including the urban space and the environmental resources linked to it), so did the plans in each district. Moreover, not only have recent plans, such as that implemented in Ine, been congruent with the shift in the national valuation criteria, but older plans, such as that implemented in Uchiko, have also evolved in harmony with those criteria, even contributing with original approaches to the whole question of the preservation. In this shift, the local community has progressively increased its importance as an actor, being acknowledged as guarantors of the function of townscapes as living environments, while at the same time being the source of traditional knowledge linked to the creation and exploitation of such living environments.

At the same time, the preservation system as a whole has room for improvement. First of all, the denken chiku system and the conservation plans in their entirety seem insufficient to the challenge of countering the main problem threatening the continuity of the protected districts, namely their progressive depopulation. While the towns designated as denken chiku had effectively worked for the protection of built structures as compared to those districts which have not been designated, the fact remains that both designated and non-designated towns have similar rates of depopulation, as stated by some recent studies. ${ }^{26}$ In conclusion, it is clear that the protection plans must be incorporated into wider plans aimed at guaranteeing the future viability of local communities.

Secondly, as can be seen from the problems between the interior and exterior spaces in Uchiko, as well as in the lack of a clear definition of what constitutes the current urban façade of Ine, Japanese townscape protection struggles in the face of the definition of urban places. The meaning of the term denken chiku, 'groups of traditional built structures', clearly shows how the focus is on the built structures themselves, even when discussing the environment (walls, disembarkation points, stairways, gates). None of the three case study plans defines the significance of unbuilt urban places, nor do they define ways to reappropriate these urban spaces in the event that their principal use has been altered, as is the case with the bay space in Ine. In conclusion, the definition of the significance of common spaces and their reappropriation through thorough mapping, conducted in collaboration with the local community (the only people who can convey meaning to each space), would be a desirable next step in the history of townscape preservation in Japan.

26. N. Saio and Y. Terao, "A study of sustainability of habitation in the historical preservation areas," in Journal of Architecture and Planning 79, no. 695 (January 2004), 131-139. 


\section{Bibliography}

ACA-Agency for Cultural Affairs. Rekishi wo ikashita machizukuri [Community planning that made use of history.] Tokyo, 2015.

Alvarez, J. "Significance of tourism and local communities. A study of the shift in valuation criteria of Japanese protected townscapes." In Journal of Architecture and Planning 82, no. 736 (2017), 1619-1629.

Hohn, U. "Townscape Preservation in Japanese Urban Planning." In The Town Planning Review 68, no. 2 (April 1997), 213-255.

Ine Town. Ine Ura dentōteki kenzōbutsugun hozon taisaku chōsa hōkokusho [Research report on the countermeasures for the preservation of Ine Ura group of traditional structures.] Ine, 2004.

Ine Town. Ine Ura dentōteki kenzōbutsugun hozon taisaku chōsa hōkokusho gaiyōhan [Research summary on the countermeasures for the preservation of Ine Ura group of traditional structures.] Ine, 2005.

Ine Town. Ine chō dentōteki kenzōbutsugun hozon chiku hozon keikaku [Preservation plan for the important district of traditional structures of Ine Town.] Ine, 2005.

Ine Town. Machizukuri no tebiki [Handbook of community planning.] Ine, 2012.

Kerr, A. Utsukushiki Nihon no zanzō [Lost Japan.]Tokyo: Shinchosha, 1993.

Kobayashi, F. and M. Kawakami. "Policies implemented in the application process of preservation districts for groups of historic buildings." In Journal of Architecture and Planning 68, no. 567 (May 2003), 87-94.

Kurayoshi City. Kurayoshi shōka machinami taisaku chōsa hōkokusho [Research report on the countermeasures for the merchant house townscape in Kurayoshi.] Kurayoshi, 1980.

Kurayoshi City. Kurayoshi shi Utsubuki Tamagawa dentōteki kenzōbutsugun hozon chiku hozon keikaku [Preservation plan for the important district of traditional structures of Utsubuki Tamagawa, Kurayoshi city.] Kurayoshi, 2001.

Kurayoshi City. Kurayoshi shi Utsubuki Tamagawa dentōteki kenzōbutsugun hozon chiku minaoshi chōsa hōkokusho [Revision research report on the important district of traditional structures of Utsubuki Tamagawa, Kurayoshi city.] Kurayoshi, 2009.

Matsumoto, S. "Gyogyō shūraku ni okeru kōtsū seikatsu. Kyōto fu Ine chō ni okeru kesu sutadi" [Traffic and life in fishermen villages. Case study of Ine Town, Kyoto prefecture.] in Toshi keikaku ronbunshū, no. 15 (November 1980).

Mori, M. Hankotsu no kōmuin machi wo migaku: Uchiko chō Okada Fumiyoshi no machinami muranami hozon [Rebel civil servant brushing up the town: Preservation of urban and rural townscapes by Fumiyoshi Okada.] Tokyo: Akishobō, 2014.

Myojo, T. "Funayatai no mawari butai ni tsuite. Kyōto fu Yosa gun Ine chō tairyō matsuri" [Stages around funaya. Great festival in Ine Town, Yosa district, Kyoto prefecture.] In Nihon engeki gakkai kiyō, no. 12 (March 1971), 48-55.

Nariwa Town, Board of Education. Bicchu Fukiya: machinami chōsa hōkokusho [Bicchu Fukiya: Research report on the townscape.] Nariwa, 1977.

Nishiyama, U. Rekishiteki keikan to machizukuri [Historical landscapes and community planning.] Tokyo: Toshi Bunkasha, 1990.

Nishimura, Y. Shōgen. Machinami hozon [Testimony: Townscape preservation.] Kyoto: Gakugei shuppansha, 2007.

Nitschke, G. "Protection of urban place of Kyoto." In Hozon: Architectural and urban conservation in Japan. Edited by Siegfried RCT Enders and Niels Gutschow. Stuttgart/London: Edition Axel Menges, 1998. 
Okada, F. "Jūmin to rekishi isan mamori katsuseika. Machinami hozon de 'kaku' takameru" [Citizens and protection-revitalisation of historical heritage. Enhancing the status through townscape preservation.] In Shōgai fōramu, no. 1163 (October 1996), 19-23.

Okada, F. "Jūmin sanka ni yoru muranami hozon" [Rural townscape preservation through citizen participation.] In Gekkan jichi fōramu, no.483 (December 1999), 34-39.

Saio, N. and Y. Terao. "A study of sustainability of habitation in the historical preservation areas." In Journal of Architecture and Planning 79, no. 695 (January 2004), 131-139.

Seizawa, S. "Sekai isan no hozon to katsuyō wo sasaeru shakaiteki nettowāku. Gifu ken Shirakawa mura to Betonamu Hoian no jirei kara" [Social network supporting the preservation and use of world heritage. Examples of Shirakawa village and Hoian, Vietnam.] In Bulletin of Research Institute 14 (2006), 75-95.

Uchiko Town. Uchiko chō dentōteki kenzōbutsugun chōsa hōkokusho [Research report on the important district of traditional structures of Uchiko town.] Uchiko, 1978.

Uchiko Town. Uchiko chō Yōkaichi Gokoku dentōteki kenzōbutsugun hozon chiku hozon taisakuhi hojokin kôfuyōmō [Money grant network for the countermeasures for the preservation of the important district of traditional structures of Uchiko town.] Uchiko, 1982.

Uchiko Town. Uchiko no 'hikari' wo 'mi' naosō. Uchiko chō kankō shinkō keikakusho [Let us re-examine the light of Uchiko. Plan for the promotion of tourism in Uchiko town.] Uchiko, 1983.

Uchiko Town. Uchiko Muikaichi-Yōkaichi Gokoku chiku. Dentōteki kenzōbutsugun hozon chiku hozon taisaku chōsa hōkokusho [Muikaichi-Yōkaichi Gokoku district, Uchiko. Research report on the countermeasures for the preservation of the important district of traditional structures.] Uchiko, 1987.

Uchiko Town. Shūri shūkei kiroku. Uchiko chō Yōkaichi Gokoku dentōteki kenzōbutsugun hozon chiku [Record of restoration and harmonization works. Yōkaichi Gokoku important district of traditional structures, Uchiko town.] Uchiko, 2013.

Uchiko Town. Yōkaichi Gokoku. Uchiko chō dentōteki kenzōbutsugun hozon chiku minaoshi chōsa hōkokusho [Yōkaichi Gokoku. Revision research report on the important district of traditional structures of Uchiko town.] Uchiko, 2013.

Yamasaki, M. "Control tools for conservation of historic townscape with citizens' strong property right: Experience of Kyoto." In ICOMOS 15th General Assembly and Scientific Symposium. 2005. 